\title{
PENGATURAN KOORDINASI PENGENDALIAN KEAMANAN ANTARA KANTOR PUSAT DIREKTORAT KEAMANAN PENERBANGAN DAN KANTOR OTORITAS BANDAR UDARA (Studi di Kantor Otoritas Bandar Udara Wilayah VI Padang)
}

\author{
Dani Adrian \\ Program Studi Pascasarjana Ilmu Hukum \\ Universitas Ekasakti Padang
}

\begin{abstract}
Fulfillment of rules against a high standard of aviation security is an absolute necessity in the aviation world. The arrangement of the coordination of aviation security control between the Head Office of the Directorate of Aviation Security and the Office of the Airport Authority is essential to protect the safety, regularity, and efficiency of civil aviation activities in its territory. The implementation of the flight security control coordination arrangement between the Head Office of the Directorate of Aviation Security and the Office of the Airport Authority has a problem namely the Directorate of Aviation Security still performs the functions of the controlling activities, the authority of signing the extension of licensing to the Head of the Office of the Authority Authority has not been implemented, the aviation security inspector's mutation from the Aviation Security Directorate's Head Office has not worked properly, and the fulfillment and distribution of budgetary requirements for the implementation of the control and supervision of the Office of the Airport Authority has not been met.
\end{abstract}

Kata Kunci: Direktorat Keamanan Penerbangan, Koordinasi Pengendalian Keamanan, Otoritas Bandar Udar.

\section{PENDAHULUAN}

Penerbangan merupakan bagian dari sistem transportasi yang mempunyai

${ }^{1}$ Perkembangan teknologi penerbangan mempunyai dampak yang positif terhadap keamanan penerbangan dalam dan luar negeri. $^{2}$

Pemenuhan aturan terhadap suatu standar keamanan penerbangan yang tinggi merupakan suatu keharusan mutlak.

\footnotetext{
${ }^{1}$ Ibid, hlm 2

${ }^{2}$ Yaddy Supriadi, Keselamatan Penerbangan Teori \& Problematika, Telaga Ilmu Indonesia, Tangerang, 2012, hlm.57
}

karakteristik mampu bergerak dalam waktu cepat, menggunakan teknologi tinggi, padat modal, manajemen yang handal, serta memerlukan jaminan keselamatan dan keamanan optimal.

Penerapan peraturan tentang keamanan penerbangan perlu dilaksanakan pada semua sektor, baik pada bandar udara, badan usaha angkutan udara, navigasi penerbangan, serta pelatihan yang mengacu pada aturan International Civil Aviation Organization $(I C A O) .^{3}$

3 http://lontar.ui.ac.id., diakses pada tanggal 01 Februari 2018 
Keamanan penerbangan adalah suatu keadaan yang memberikan perlindungan kepada penerbangan dari tindakan yang melawan hukum (acts of unlawful interference) melalui keterpaduan pemanfaatan sumber daya manusia, fasilitas dan prosedur. ${ }^{4}$ Juga keadaan yang terwujud dari penyelenggaraan transportasi yang lancar sesuai dengan standar operasional prosedur dan persyaratan teknis sumber daya manusia dalam mengoperasikan sarana dan prasarana penerbangan beserta penunjangnya. ${ }^{5}$

Adanya UU Nomor 1 Tahun 2009 tentang penerbangan dimaksudkan antara lain untuk meningkatkan fungsi pembinaan penerbangan sipil yang meliputi aspek pengaturan, aspek pengendalian, dan aspek pengawasan. Undang-Undang ini membawa perubahan baru yaitu membentuk Unit Pelaksana Teknis di lingkungan Kementerian Perhubungan yang berada di bawah dan bertanggung jawab kepada Menteri Perhubungan melalui Direktur Jenderal Perhubungan Udara untuk menjamin keselamatan, keamanan, dan pelayanan penerbangan di Indonesia. ${ }^{6}$

Pada tahun 2011 lahirlah Peraturan Menteri Perhubungan Nomor PM. 41 Tahun 2011 tentang Organisasi dan Tata Kerja

4 Bab II Ketentuan Umum, Peraturan Menteri Perhubungan Nomor :PM 80 Tahun 2017 tentang Program Keamanan Penerbangan Nasiona

5 www,indonesiaairport.co.id, diakses pada tanggal 1 Februari 2018

6 Pasal 231 UU Nomor 1 Tahun 2009 tentang Penerbangan
Kantor Otoritas Bandar Udara. Kewenangan terkait ketentuan kedudukan dan hubungan pertanggungjawaban Kantor Otoritas Bandar Udara dalam pelaksanaannya dilimpahkan kepada Direktur Jenderal Perhubungan Udara. $^{7}$ Dalam rangka mendukung kegiatan Kantor Otoritas Bandar Udara dipimpin oleh seorang Kepala Kantor Otoritas Bandar Udara mempunyai tugas melaksanakan pengaturan, pengendalian, dan pengawasan kegiatan penerbangan di Bandar udara. ${ }^{8}$

Dirjen Perhubungan Udara mempunyai tugas menyelenggarakan perumusan dan pelaksanaan kebijakan di bidang penerbangan yang berada di bawah dan bertanggung jawab kepada Menteri yang dipimpin oleh seorang Direktur Jenderal Perhubungan Udara.

Pelaksanaan pemberian bimbingan teknis dan supervisi di bidang keamanan penerbangan (aviation security) dilingkungan Direktorat Jenderal Perhubungan Udara dilaksanakan oleh Direktorat Keamanan Penerbangan yang dipimpin oleh seorang Direktur Keamanan Penerbangan, mempunyai tugas melaksanakan perumusan dan pelaksanaan kebijakan, penyusunan norma, standar, prosedur, dan kriteria, pemberian bimbingan teknis dan supervise

\footnotetext{
7 Pasal 1 ayat (2) Peraturan Menteri Perhubungan Nomor: PM. 41 Tahun 2011 tentang Organisasi dan Tata Kerja Kantor Otoritas Bandar Udara

8 Pasal 1 ayat (3) Peraturan Menteri Perhubungan Nomor: PM. 41 Tahun 2011 tentang Organisasi dan Tata Kerja Kantor Otoritas Bandar Udara
} 
serta evaluasi dan pelaporan di bidang keamanan penerbangan.

Berdasarkan hasil observasi peneliti permasalahan yang dihadapi dalam pelaksanaan pengaturan koordinasi pengendalian keamanan penerbangan antara Kantor Pusat Direktorat Keamanan Penerbangan dan Kantor Otoritas Bandar Udara diantaranya adalah Direktorat Keamanan Penerbangan sampai saat ini masih melaksanakan tugas fungsi kegiatan pengendalian yang seharusnya kegiatan tersebut dilaksanakan oleh Kantor Otoritas Bandar Udara, kewenangan penandatanganan perpanjangan perizinan yang diberikan Direktur Jenderal Perhubungan Udara kepada Kepala Kantor Otoritas Bandar Udara sampai saat ini belum dilaksanakan dikarenakan implementasi pemberian kewenangan masih dilaksanakan oleh Direktorat Keamanan Penerbangan, dan Penempatan Inspektur Penerbangan, khususnya Inspektur Keamanan Penerbangan belum disesuaikan dengan jumlah dan kualifikasi untuk mendukung fungsi program pengendalian dan pengawasan Kantor Otoritas Bandar Udara. ${ }^{9}$

Berdasarkan uraian yang telah dipaparkan di atas, maka penulis melakukan penelitian ilmiah dengan mengambil judul "Pengaturan Koordinasi Pengendalian Keamanan Penerbangan Antara Kantor Pusat

${ }^{9}$ Peraturan Menteri Perhubungan Nomor: PM. 59 Tahun 2015 tentang Kriteria, Tugas, dan Wewenang Inspektur Penerbangan
Direktorat Keamanan Penerbangan dan Kantor Otoritas Bandar Udara".

Berdasarkan latar belakang masalah pada uraian di atas, maka dapat dirumuskan permasalahan sebagai berikut:

Bagaimanakah pengaturan koordinasi pengendalian keamanan penerbangan antara Kantor Pusat Direktorat Keamanan Penerbangan dan Kantor Otoritas Bandar Udara? (2) Kendala-kendala apa saja yang ditemukan dalam pengaturan koordinasi keamanan penerbangan antara Kantor Pusat Direktorat Keamanan Penerbangan dan Kantor Otoritas Bandar Udara.

\section{PEMBAHASAN}

\section{Pengertian Pengaturan}

Pengaturan menekankan pada proses, cara, perbuatan dalam pelaksanaan atau penyelenggaraan suatu kegiatan. Konsep "pengaturan pemerintahan" menekankan pada proses, cara dan perbuatan mengatur dalam menyelenggarakan pemerintahan. Pada Bab III Undang-undang Dasar Negara Republik Indonesia 1945 mengatur tentang kekuasaan pemerintahan negara, yang dalam ketentual pasal 5, menentukan "Presiden berhak mengajukan rancangan Undang-undang kepada Dewan Perwakilan Rakyat".

Sedangkan pengertian "pengaturan" menurut penelitian ini adalah meliputi 
penetapan, kebijakan umum dan teknis yang terdiri atas penentuan norma, standar, pedoman, kriteria, perencanaan, dan prosedur termasuk persyaratan keselamatan dan keamanan penerbangan serta perizinan.

\section{Pengertian Koordinasi}

Pada hakekatnya koordinasi adalah mewujudkan daripada kerjasama, saling membantu dan menghargai, menghayati tugas dan fungsi serta tanggung jawab masingmasing. Hal ini disebabkan karena setiap satuan kerja atau bantuan dari satuan kerja (unit) yang lain. Jadi adanya ketergantungan atau interdepedensi inilah yang mendorong adanya kerjasama.

Koordinasi adalah proses saling mengerti antara dua orang atau lebih untuk melaksanakan suatu hal. Proses yang harus dijalani agar suatu kegiatan dapat dilaksanakan dengan lancar ataupun jika ada masalah tidak akan terlalu banyak kesulitan untuk mengatasinya. Menurut Awaluddin Djamin, koordinasi diartikan sebagai suatu usaha kerja sama antara badan, instansi, unit dalam pelaksanaan tugas-tugas tertentu, sehingga terdapat saling mengisi, saling membantu dan saling melengkapi. Dengan demikian koordinasi dapat diartikan sebagai suatu usaha yang mampu menyelaraskan

10 Awaluddin Djamin dalam Hasibuan, Manajemen Sumber Daya Manusia, Bumi Aksara, Bandung, 2007, hlm 20 pelaksanaan tugas maupun kegiatan dalam suatu organisasi. ${ }^{10}$

Koordinasi memiliki ciri yaitu suatu proses dalam melakukan kerjasama yang merupakan konsep kesatuan tindakan secara teratur dan tanggung jawab terletak pada pimpinan.

Koordinasi memiliki beberapa fungsi yaitu sebagai salah satu fungsi manajemen, menjamin kelancaran mekanisme prosedur kerja dari berbagai komponen dalam organisasi, sebagai usaha yang mengarahkan dan menyatukan kegiatan yang mengandung makna adanya keterpaduan yang dilakukan secara serasi dan simultan, sebagai faktor dominan dalam kelangsungan hidup suatu organisasi pada tingkat tertentu, untuk melahirkan jaringan hubungan kerja atau komunikasi, sebagai usaha untuk menyelaraskan setiap tindakan, langkah, dan sikap, serta untuk pentaan spesialisasi dalam berbagai keanekaragaman tugas. ${ }^{11}$

Faktor-faktor yang dapat menghambat tercapainya koordinasi adalah : ${ }^{12}$
a. Hambatan-hambatan dalam koordinasi vertikal (struktural)
b. Hambatan-hambatan dalam koordinasi fungsional


Hal-hal yang biasanya menjadi hambatan dalam pelaksanaan koordinasi antara lain:

a. Para pejabat sering kurang menyadari bahwa tugas yang dilaksanakannya hanyalah merupakan sebagian saja dari keseluruhan tugas dalam organisasi untuk mencapai tujuan organisasi tersebut

b. Para pejabat sering memandang tugasnya sebdiri sebagai tugas yang paling penting dibandingkan dengan tugas-tugas lain

c. Adanya pembagian kerja atau spesialisasi yang berlebihan dalam organisasi

d. Kurang jelasnya rumusan tugas atau fungsi, wewenang dan tanggungjawab dari masing-masing pejabat atau satuan organisasi

e. Adanya prosedur dan tata kerja yang kurang jelas dan berbelit-belit dan tidak diketahui oleh semua pihak yang bersangkutan dalam usaha kerja sama.

f. Kurangnya kemampuan dari pimpinan untuk menjalankan koordinasi yang disebabkan oleh kurangnya kecakapan, wewenang dan kewibawaan.

g. Tidak atau kurangnya forum komunikasi diantara para pejabat yang bersangkutan yang dapat dilakukan dengan saling tukar menukar informasi dan diciptakan adanya saling pengertian guna kelancaran pelaksanaan kerjasama.

13 Ndraha, Taliziduhu. Kybernology (Ilmu Pemerintahan Baru) Jilid 1. PT. Rineka Cipta. Jakarta, 2003, hlm 295.
Hambatan dalam koordinasi antara Kantor Pusat Direktorat Keamanan Penerbangan dan Kantor Otoritas Bandar Udara dalam pengaturan pengendalian di bidang keamanan penerbangan adalah hambatan fungsional, yaitu hambtan yang disebabkan karena tidak terdapat hubungan hierarkis (garis komando), sedangkan hubungan keduanya terjadi karena adanya kaitan yaitu pengaturan di bidang pengendalian keamanan penerbangan.

Tujuan adanya koordinasi adalah menciptakan dan memelihara efektivitas organisasi setinggi mungkin melalui sinkronisasi, penyerasian, kebersamaan, dan kesinambungan, antar berbagai dependen suatu organisasi, mencegah konflik dan menciptakan efisiensi setinggitingginya setiap kegiatan interpenden yang berbeda-beda melalui kesepakatan - kesepakatan yang mengikat semua pihak yang bersangkutan, dan menciptakan serta memelihara iklim dan sikap saling responsif-antisipatif di kalangan unit kerja interpenden dan independen yang berbedabeda, agar keberhasilan unit kerja yang satu tidak rusak oleh keberhasilan unit kerja yang lain, melalui jaringan informasi dan komunikasi efektif. ${ }^{13}$

\section{Fungsi Pengendalian Keamanan}


Dalam Pasal 1 angka 49 Undangundang Nomor 1 Tahun 2009 tentang penerbangan, keamanan penerbangan adalah suatu keadaan yang memberikan perlindungan kepada penerbangan dari tindakan melawan hukum melalui keterpaduan pemanfaatan sumber daya manusia, fasilitas dan prosedur. ${ }^{14}$

Untuk memastikan konsistensi kualitas personel dan fasilitas keamanan penerbangan, maka dari itu Direktorat Jenderal Perhubungan Udara menyerahkan sebagian fungsi pengendalian sesuai dengan wilayah kerjanya kepada Kantor Otoritas Bandar Udara yang termuat pada pasal 3 point (e) dalam Peraturan Menteri Perhubungan Nomor : PM. 22 Tahun 2015 tentang Organisasi dan Tata Kerja Kantor Otoritas Bandar Udara untuk melaksanakan fungsi pemberian arahan, bimbingan, perpanjangan perizinan (Izin, sertifkat fasilitas/peralatan/organisasi dan Lisensi Personel) bidang keamanan penerbangan.

\section{Peran Pengendalian Keamanan \\ Penerbangan oleh Kantor Otoritas Bandar Udara}

Kewenangan Kepala Kantor Otoritas Bandar Udara dalam menjalankan tugas dan tanggung jawab menjamin terlaksana dan terpenuhinya ketentuan keamanan adalah $:^{15}$

14 Pasal 3 ayat (1) Peraturan Direktur Jenderal Perhubungan Udara Nomor: KP. 459 Tahun 2015 tentang Petunjuk Pelaksanaan Peraturan Menteri Perhubungan Nomor: PM. 41 Tahun 2011 tentang a. Mengkoordinasikan dan mengawasi kegiatan pemerintahan di Bandar Udara

b. Mengendalikan dan mengawasi pelaksanaan ketentuan keamanan penerbangan di Bandar Udara

c. Mengendalikan dan mengawasi pelaksanaan standar kinerja operasional keamanan penerbangan di Bandar Udara

d. Menyusun, menetapkan prosedur dan meneribitkan izin masuk Daerah Keamanan Terbatas di Bandar Udara

e. Memastikan komite keamanan bandar udara melaksanakan pertemuan rutin

f. Mengesahkan revisi program keamanan bandar udara

g. Memberikan tindakan korektif dan sanski administratif kepada Badan Usaha Bandar Udara, Unit Penyelenggara Bandar Udara, Unit Penyelenggara Bandar Udara, Badan Usaha Angkutan Udara, Penyelenggara Navigasi Penerbangan, Badan Hukum Yang Mendapat Pendelegasian dan Lembaga Penyelenggara Pendidikan dan Pelatihan yang tidak memenuhi ketentuan Keamanan Penerbangan sesuai dengan peraturan perundangundangan

h. Mengesahkan Prosedur Keamanan Statsiun (Station Security Manual) yang merupakan Lampiran Program Keamanan Angkutan Udara

Organisasi dan Tata Kerja Kantor Otoritas Bandar Udara.

15 Point 3.3 Peraturan Menteri Perhubungan Nomor: PM. 80 Tahun 2017 tentang Program Keamanan Penerbangan Nasional 
i. Mengesahkan Prodesur Keamanan Lokal (Local Security Manual) yang merupakan lampiran Program Keamanan Perusahaan Angkutan Udara Asing

j. Melakukan evaluasi terhadap keberlakuan lisensi personel keamanan penerbangan

k. Melaporkan kegiatan pengawasan dan pengendalian terhadap pelaksanaan keamanan penerbangan di wilayah kerjanya kepada Direktur Jenderal Perhubungan Udara setiap 1 (satu) bulan

1. Melakukan penilaian kerentanan (vulnerability assessment) daerahdaerah yang berpotensi dilakukan peluncuran sistem senajata panggul (Man-Portable Air Defense Systems MANPADS) di Bandar Udara berdasarkan penilaian resiko dan memberikan langkah-langkah mitigasinya (mitigation plan).

\section{Tugas dan Fungsi Kantor Pusat Direktorat Keamanan Penerbangan dalam Pengaturan Pengendalian}

\section{Keamanan Penerbangan}

Kantor Pusat Direktorat Keamanan Penerbangan mempunyai tugas melaksanakan perumusan dan pelaksanaan kebijakan penyusunan norma, standar, prosedur, dan kriteria, pemberian bimbingan teknis dan supervisi, serta evaluasi dan pelaporan di bidang keamanan penerbangan.

16 Pasal 484 Peraturan Menteri Perhubungan Nomor: PM. 189 tentang Organisasi dan Tata Kerja Kementerian Perhubungan
Dalam melaksanakan tugas Kantor Pusat Direktorat Keamanan Penerbangan menyelenggarakan fungsi : ${ }^{16}$

a. Penyiapan perumusan kebijakan dibidang standarisasi, kerjasama dan program keamanan penerbangan, pelayanan darurat, Penyidik Pegawai Negeri Sipil dan personel keamanan penerbangan, fasilitas keamanan penerbangan, kargo dan barang berbahaya, serta kendali mutu keamanan penerbangan

b. Penyiapan pelaksanaan kebijakan di bidang standarisasi, kerjasama dan program keamanan penerbangan, pelayanan darurat, penyidik Pegawai Negeri Sipil dan personel keamanan penerbangan, kargo dan barang berbahaya, serta kendali mutu keamanan penerbangan

c. Penyiapan penyusunan, norma, standar, prosedur, dan kriteria dibidang standarisasi, kerjasama dan program keamanan penerbangan, pelayanan darurat penyidik Pegawai Negeri Sipil dan personel keamanan penerbangan, fasilitas keamanan penerbangan, kargo dan barang berbahaya, serta kendali mutu keamanan penerbangan

d. Penyiapan pelaksanaan bimbingan teknis dan supervisi di bidang standarisasi, kerjasama dan program keamanan penerbangan, pelayanan darurat, Penyidik 
Pegawai Negeri Sipil dan Personel Keamanan Penerbangan, kargo dan barang berbahaya, serta kendali mutu keamanan penerbangan

e. Pelaksanaan evaluasi dan pelaporan di bidang standarisasi, kerjasama dan program keamanan penerbangan, pelayanan darurat, Penyidik Pegawai Negeri Sipil dan Personel keamanan penerbangan, fasilitas keamanan penerbangan, kargo dan barang berbahaya, serta kendali mutu keamanan penerbangan

f. Penyiapan pelaksanaan urusan tata usaha, keuangan, kepegawaian dan rumah tangga Direktorat yang meliputi perencanaan, pengelolaan sistem teknologi informatika, dan dokumentasi teknis, penyiapan bahan pelaporan, serta administrasi PNBP

\section{Direktorat Keamanan Penerbangan}

Direktorat Keamanan Penerbangan adalah unsur pelaksana sebagian tugas dan fungsi Direktur Jenderal Perhubungan Udara, yang mempunyai tugas melaksanakan perumusan dan pelaksanaan kebijakan, penyusunan norma, standar, prosedur, dan kriteria, pemberian bimbingan teknis dan supervisi, serta evaluasi dan pelaporan di bidang keamanan penerbangan.

\section{Kantor Otoritas Bandar Udara}

Kantor Otoritas Bandar Udara adalah Unit Pelaksana Teknis di lingkungan Kementerian Perhubungan yang berada di bawah dan bertanggung jawab kepada Menteri Perhubungan melalui Direktur Jenderal Perhubungan Udara.

Pelaksanaan kewenangan kegiatan pengendalian keamanan penerbangan pada Kantor Otoritas Bandar Udara Wilayah VI Padang yang meliputi kegiatan pemberian arahan, bimbingan teknis, bantuan teknis, perpanjangan perizinan (izin, sertifkat, Fasilitas / Peralatan / Organisasi dan Lisensi Personel) menjadi fungsi seorang Kepala Kantor Otoritas Bandar Udara yang dalam hal ini fungsi tersebut dapat didelegasikan kepada pejabat setingkat dibawahnya yaitu kepada Kepala Seksi Keamanan Angkutan Udara dan Kelaikudaraan.

Pengaturan koordinasi pelaksanaan fungsi pengendalian dan pengawasan antara Kantor Pusat Direktorat Keamanan Penerbangan dan Kantor Otoritas Bandar Udara setelah ditetapkannya Peraturan Menteri Perhubungan Nomor: PM 41 Tahun 2011 seharusnya dilakukan secara harmonis dan berjenjang untuk dilaksanakan oleh Inspektur Keamanan Penerbangan Kantor Otoritas Bandar Udara sesuai dengan cakupan wilayah kerjanya. Pasal 9 Peraturan Menteri Perhubungan Nomor : PM. 22 Tahun 2015 tentang Peningkatan Fungsi Pengendalian dan Pengawasan Oleh Kantor Otoritas Bandar Udara, secara tegas menyatakan bahwa dalam rangka memenuhi fungsi pengendalian dan pengawasan Kantor Otoritas Bandar Udara perlu pengaturan penempatan inspektur 
penerbangan pada masing-masing Kantor Otoritas Bandar Udara dengan jumlah dan kualifikasi ditentukan berdasarkan kebutuhan dan beban kerja yang ditetapkan Direktur Jenderal. Pemenuhan kebutuhan Inspektur Penerbangan dilakukan melalui pola mutasi inspektur penerbangan dari Kantor Pusat Direktorat Jenderal Perhubungan Udara atau dari Kantor Otoritas Bandar Udara.

Menurut Pasal 5 dan Pasal 6 dalam Peraturan Direktur Jenderal Perhubungan Udara Nomor : KP. 459 Tahun 2015 tentang Petunjuk Pelaksanaan Peraturan Menteri Perhubungan Nomor : PM. 41 Tahun 2011 tentang Organisasi dan Tata Kerja Kantor Otoritas Bandar Udara, dalam hal Kantor Otoritas Bandar Udara tidak memiliki sumber daya manusia (SDM) yang memiliki kompetensi dan peralatan yang memenuhi standar maka pelaksanaan fungsi pengendalian dan pengawasan dikoordinasikan dengan Kantor Pusat Direktorat Jenderal Perhubungan Udara melalui sistem database keselamatan dan keamanan penerbangan nasional. ${ }^{17}$ Akan tetapi sampai dengan saat ini database yang terintegrasi sesuai dengan amanah dari Peraturan Direktur Jenderal Perhubungan Udara Nomor: KP. 459 Tahun 2015 belum tersedia.

17 Pasal 6 Peraturan Direktur Jenderal Perhubungan Udara Nomor: KP. 459 Tahun 2015 tentang Petunjuk Pelaksanaan Peraturan Menteri Perhubungan Nomor: PM. 41 Tahun 2011 tentang
Pelaksanaan Fungsi Pengendalian

\section{Direktorat Keamanan Penerbangan}

Pengaturan koordinasi pengendalian keamanan penerbangan antara Kantor Pusat Direktorat Keamanan Penerbangan dan Kantor Otoritas Bandar Udara adalah bentuk Koordinasi Fungsional yang artinya adalanya penyelarasan kerjasama secara harmonis dan sinkron antar lembaga-lembaga yang memiliki kesamaan dalam fungsi pekerjaan.

Akan tetapi dalam pelaksanaannya Kantor Otoritas Bandar Udara Wilayah VIPadang yang mempunyai tugas pokok dan fungsi pelaksanaan pengendalian yang termasuk kegiatan pemberian arahan, bimbingan, bantuan teknis, perpanjangan perizinan sebagaimana amanah dari Peraturan Menteri perhubungan Nomor : PM. 41 Tahun 2011 tentang Organisasi dan Tata Kerja Kantor Otoritas Bandar Udara dan Peraturan Menteri Perhubungan Nomor : PM. 22 Tahun 2015 tentang peningkatan fungsi Pengendalian dan Pengawasan Kantor Otoritas Bandar Udara sampai saat ini belum bisa melaksanakan tugas pokok dan fungsi tersebut dikarenakan kegiatan pengendalian keamanan penerbangan terkait perpanjangan masih dilaksanakan oleh Kantor Pusat Direktorat Keamanan Penerbangan. ${ }^{18}$

\footnotetext{
Organisasi dan Tata Kerja Kantor Otoritas Bandar udara

18 Wawancara dengan Bapak Suparlan, Kepala Seksi Keamanan Angkatan Udara dan
} 
Berdasarkan Peraturan Direktur Jenderal Perhubungan Udara Nomor : KP. 459 Tahun 2015 tentang Petunjuk Teknis Pelaksanaan Peraturan Menteri Perhubungan Nomor : PM. 41 Tahun 2011 tentang Organisasi dan Tata Kerja Kantor Otoritas Bandar Udara, telah dijelaskan bahwa pelaksanaan fungsi pengendalian berupa pemberihan arahan, bimbingan, pemberian dan perpanjangan izin (personel. Fasilitas, peralatan, dan organisasi) bidang keamanan penerbangan dilaksanakan oleh Kantor Otoritas Bandar Udara wilayah VI - Padang.

Perpanjangan perizinan personel keamanan bandar udara dan perpanjangan sertifikat fasilitas keamanan bandar udara di wilayah kerja merupakan proses fungsi pengendalian yang dilakukan oleh Inspektur Keamanan Penerbangan Kantor Otoritas Bandar Udara Wilayah VI - Padang secara teknis dan administrative. Proses penandatanganan lisensi dan sertifikat tersebut merupakan kewenangan dari Kepala Kantor Otoritas Bandar Udara yang dapat didelegasikan kepada pejabat setingkat dibawahnya yaitu Kepala Seksi Keamanan Angkutan Udara dan Kelaikudaraan. ${ }^{19}$

Tanggung jawab Inspektur Keamanan Penerbangan Kantor Otoritas Bandar Udara

Kelaikudaraan Kantor Otoritas Bandar Udara Wilayah VI-Padang, 2 Maret 2018

19 Wawancara dengan Bapak Kol. Penerbang Nailul Humam, Kepala Kantor Otoritas Bandar Udara Wilayah VI - Padang, 8 Maret 2018
Wilayah VI - Padang sangat berat dalam menjamin keselamatan dan keamanan penerbangan, karena inspektur keamanan penerbangan merupakan jabatan independen di penerbangan yang diberi tugas, tanggung jawab, dan hak secara penuh oleh Direktur Jenderal Perhubungan Udara untuk melakukan kegiatan pengawasan keselamatan, keamanan dan pelayanan penerbangan. ${ }^{20}$

Pengaturan Pengendalian berupa arahan, bimbingan, perizinan dan sertifikasi bidang Keamanan Penerbangan yang dilakukan oleh Inspektur Kantor Otoritas Bandar Udara dalam mewujudkan keselamatan, keamanan dan pelayanan penerbangan di wilayah kerjanya sudah dilaksanakan dengan baik, hal tersebut dapat dilihat dengan pelaksanaan kegiatan sosialisasi peraturan perundang-undangan, bimbingan teknis, workshop bidang keamanan penerbangan dan forum diskusi grup (FGD). ${ }^{21}$

Pengaturan pengendalian dalam upaya mewujudkan keselamatan, keamanan dan pelayanan penerbangan di wilayah kerjanya sangat baik dalam menjalankan atau melaksanakan tugasnya, tetapi belum maksimal karena peran fungsi pengendalian

\footnotetext{
20 Wawancara dengan Bapak Erwin Zein, Kepala Sub Bagian Tata Usaha Kantor Otoritas Bandar Udara Wilayah VI-Padang, 27 Maret 2018

21 Wawancara dengan Bapak Suparlan, Kepala Seksi Keamanan Angkatan Udara dan Kelaikudaraan Kepala kantor Otoritas Bandar Udara Wilayah VI-Padang, 9 Maret 2018
} 
seperti perpanjangan lisensi personel dan fasilitas keamanan Bandar udara di wilayah kerjanya masih dilaksanakan oleh Inspektur Keamanan Direktorat Keamanan Penerbangan.

Kantor Otoritas Bandar Udara Wilayah VI - Padang dalam pelaksanaan pengendalian keamanan penerbangan telah menerapkan SOP terkait Tata Cara Prosedur Perpanjangan Lisensi Personel Keamanan Penerbangan dan fasilitas perpanjang lisensi seperti: gedung laboratorium lisensi personel/computer base training (CBT), dan gedung simulator $\mathrm{x}$-ray. ${ }^{22}$

$$
\text { Peraturan Menteri Perhubungan }
$$

Nomor: PM. 41 Tahun 2011 tentang Organisasi dan Tata Kerja Kantor Otoritas Bandar Udara dijelaskan bahwa salah satu fungsi dari Kantor Otoritas Bandar Udara Wilayah VI - Padang adalah pelaksanaan pengendalian berupa pemberian arahan, bimbingan, bantuan teknis, perpanjang perizinan (Izin, Sertifikat, Fasilitas / Peralatan / Organisasi dan Lisensi Personel). Pengaturan perpanjangan lisensi personel keamanan penerbangan diatur secara tegas dalam Peraturan Menteri Perhubungan Nomor : PM. 80 Tahun 2017 tentang Program Keamanan Penerbangan Nasional pada BAB VIII Point 8.1 bahwa pendidikan dan pelatihan penyegaran internal personel keamanan penerbangan terkait dengan

22 Wawancara dengan Bapak Kol. Penerbang Nailul Humam, Kepala Kantor Otoritas Bandar Udara Wilayah VI - Padang, 8 Maret 2018 kompetensinya pada Bandar Udara Internasional dilaksanakan setiap 1 (satu) tahun sekali oleh Kantor Otoritas Bandar Udara. $^{23}$

\section{Pelaksanaan Fungsi Pengendalian}

\section{Keamanan Penerbangan Kantor}

Otoritas Bandar Udara

Peraturan pelaksanaan fungsi pengendalian bidang keamanan penerbangan Kantor Otoritas Bandar Udara tertuang dalam lampiran Peraturan Direktur Jenderal Perhubungan Udara Nomor: KP. 459 Tahun 2015 tentang Petunjuk Pelaksanaan Peraturan Menteri Perhubungan Nomor : PM. 41 Tahun 2011 tentang Organisasi dan Tata Kerja Kantor Otoritas Bandar Udara. Peraturan tersebut berisikan pembagian kewenangan antara Kantor Pusat dengan Kantor Otoritas Bandar Udara dalam menjalankan fungsi pengendalian dan pengawasan di bidang keamanan penerbangan. Namun fakta penerapan dilapangan justru masih banyak fungsi pengendalian yang telah diatur di dalam undang-undang, Peraturan Menteri, Peraturan Direktur Jenderal Perhubungan Udara menjadi tumpang tindih dan disharmoni.

$$
\text { Pengaturan pelaksanaan fungsi }
$$
pengendalian dan pengawasan antara Kantor Pusat dengan Kantor Otoritas Bandar Udara

\footnotetext{
23 Wawancara dengan Bapak Joko Surahman, selaku Inspektur Keamanan Penerbangan Kantor Otoritas Bandar Udara Wilayah VI - Padang, 12 Maret 2018
} 
sudah diatur dalam Pasal 4 dalam Peraturan Direktur Jenderal Perhubungan Udara Nomor : KP. 459 Tahun 2015 yang menjelaskan bahwa "Dalam pelaksanaan fungsi pengendalian dan Pengawasan Kantor Pusat Otoritas Bandar Udara harus menggunakan: a). Sumber Daya Manusia yang memliliki kompetensi di bidangnya sesuai dengan peraturan perundang-undangan $b$ ). Peralatan yang memenuhi standar keselamatan dan keananan penerbangan, dan c). Pedoman pelaksanaan pengendalian dan pengawasan sesuai dengan ketentuan Peraturan Direktur Jenderal Perhubungan Udara. Dalam hal Kantor Otoritas Bandar Udara tidak memiliki SDM yang memiliki kompetensi dan peralatan yang memenuhi standar maka pelaksanaan fungsi pengendalian dan pengawasan dikoordinasikan dengan Kantor Pusat Direktorat Jenderal Perhubungan Udara. $^{24}$

\section{Pelaksanaan Koordinasi Pengendalian}

Keamanan Penerbangan antara Kantor

Pusat Direktorat Keamanan Penerbangan dan Kantor Otoritas Bandar Udara

Koordinasi dimaksudkan sebagai usaha menyatukan kegiatan dari satuan kerja organisasi, sehingga organisasi bergerak sebagai kesatuan yang bulat guna melaksanakan seluruh tugas organisasi untuk

24 Wawancara dengan Bapak Dian Mustika Mega, selaku Inspektur Keamanan Penerbangan Kantor Otoritas Bandar Udara Wilayah VI - Padang, 17 Maret 2018 mencapai tujuannya. Fungsi koordinasi menurut Hanadayaningrat yaitu sebagai salah satu fungsi manajemen disamping adanya fungsi perencanaan, penyusunan pegawai, pembinaan kerja, motivasi, dan pengawasan untuk menjamin kelancaran mekanisme prosedur kerja dari berbagai komponen dalam organisasi, sebagai usaha yang mengarahkan dan menyatukan kegiatan yang mengandung makna adanya keterpaduan yang dilakukan secara serasi dan simultan dari seluruh tindakan yang dijalankan oleh organisasi, sebagai faktor dominan dalam kelangsungan hidup suatu organisasi pada tingkat tertentu, untuk melahirkan jaringan hubungan kerja, sebagai usaha untuk menyelaraskan setiap tindakan, dan untuk penataan spesialisasi dalam berbagai keanekaragaman tugas. ${ }^{25}$

Pengaturan koordinasi pelaksanaan fungsi pengendalian sebagaimana telah diatur di dalam Peraturan Direktur Jenderal Perhubungan Udara Nomor : KP. 459 Tahun 2015 tentang Petunjuk Pelaksanaan Peraturan Menteri Nomor : PM. 41 Tahun 2011 bahwa antara Kantor Pusat dan Kantor Otoritas Bandar Udara dilakukan secara harmonis dan berjenjang sesuai kewenangannya melalui sistem database keselamatan dan keamanan penerbangan nasional. Akan tetapi pelaksanaan pembagian kewenangan pengendalian keamanan penerbangan

25 Handayaningrat, Manajemen Konflik. PT. Gramedia Pustaka Utama. Jakarta. 1989. hlm 119. 
dilaksanakan belum sesuai dengan ketentuan, karena sistem database yang dimaksud dalam pasal 6 Peraturan Peraturan Direktur Jenderal Perhubungan Udara Nomor: KP. 459 Tahun 2015 tentang Petunjuk Pelaksanaan Peraturan Menteri Nomor : PM. 41 Tahun 2011 belum tersedia sampai saat ini di Kantor Otoritas Bandar Udara Wilayah VI - Padang.

Kondisi saat ini tentunya sangat bertentangan dengan pengertian koordinasi, karena secara normatif, koordinasi diartikan sebagai kewenangan untuk menggerakkan, menyeserasikan, menyelaraskan, dan menyeimbangkan kegiatan-kegiatan yang spesifik atau berbeda-beda agar semua terarah pada tujuan tertentu dan secara fungsional koordinasi dilakukan guna untuk mengurangi dampak negatif spesialisasi dan mengefektifkan pembagian kerja.

\section{PENUTUP}

Pengaturan koordinasi pengendalian keamanan penerbangan antara Kantor Pusat Direktorat Keamanan Penerbangan dan Kantor Otoritas Bandar Udara sangat penting untuk melindungi keselamatan, keteraturan dan efisiensi kegiatan penerbangan sipil di wilayah kerjanya melalui pemberian arahan, bimbingan teknis, bantuan teknis, workshop bidang keamanan penerbangan termasuk perpanjangan perizinan lisensi personel dan fasilitas keamanan bandar udara di wilayah kerjanya demi terwujudnya penyelenggaraan penerbangan yang tertib, teratur, selamat, aman dan nyaman. Peran fungsi pengendalian Keamanan Penerbangan di Kantor Otoritas Bandar Udara Wilayah VI - Padang telah melaksanakan tugasnya sesuai dengan tugas pokok dan fungsi yang terdapat dalam Peraturan Menteri Perhubungan Nomor : PM. 41 Tahun 2011 tentang Organisasi dan Tata Kerja Kantor Otoritas Bandar Udara.

Kendala-kendala yang ditemui dalam pengaturan koordinasi keamanan penerbangan antara Kantor Pusat Direktorat Keamanan Penerbangan dan Kantor Otoritas Bandar Udara adalah : pelaksanaan fungsi pengendalian di bidang keamanan penerbangan berupa perpanjangan lisensi personel keamanan bandar udara dan perpanjangan sertifkat fasilitas/peralatan keamanan bandar udara di wilayah kerjanya sampai saat ini masih dikerjakan oleh Inspektur Keamanan Penerbangan Kantor Pusat Direktrorat Keamanan Penerbangan. Pelaksanaan wewenang fungsi pengendalian terjadi tumpang tindih. pengaturan penempatan inspektur keamanan penerbangan pada Kantor Otoritas Bandar Udara Wilayah VI - Padang belum sesuai dengan jumlah dan kualifikasi berdasarkan kebutuhan serta beban kerja yang ditetapkan DirekturJenderal Perhubungan Udara. Pola mutasi inspektur keamanan penerbangan dari Kantor Pusat Direktorat Keamanan Penerbangan atau dari Kantor Otoritas Bandar Udara belum berjalan sebagaimana mestinya. Pemenuhan dan distribusi kebutuhan anggaran pelaksanaan 
pengendalian dan pengawasan Kantor Otoritas Bandar Udara belum terpenuhi.

Direktur Jenderal Perhubungan Udara seharusnya melakukan pembagian kewenangan serta pendelegasian di dalam fungsi pengendalian di bidang keamanan penerbangan berupa perpanjangan lisensi personel dan fasilitas/peralatan keamanan bandar udara antara Kantor Pusat Keamanan Penerbangan dan Kantor Otoritas Bandar Udara, sebaiknya melakukan revisi terhadap Peraturan Direktur Jenderal Perhubungan Udara yang mengatur tentang Petunjuk Pelaksanaan Peraturan Menteri Perhubungan Nomor : PM. 41 Tahun 2011 tentang Organisasi dan Tata Kerja Kantor Otoritas Bandar Udara.

Kantor Pusat Direktorat Keamanan Penerbangan dan Kantor Otoritas Bandar Udara Wilayah VI - Padang agar melaksanakan pengaturan koordinasi pengendalian keamanan penerbangan secara harmonis dan berjenjang sesuai dengan kewenangannya melalui sistem program keamanan penerbangan nasional.

Kepala Kantor Otoritas Bandar Udara seharusnya merekrut pegawai dengan pola pembentukan dari Kantor Unit Penyelenggara Bandar Udara untuk mutasi ke Kantor Otoritas Bandar Udara dengan batas waktu mutasi minimum 4 (empat) tahun untuk pemenuhan jumlah dan kualifikasi Inspektur Keamanan Penerbangan dalam rangka meningkatkan fungsi pengendalian di wilayah kerjanya.

\section{DAFTAR PUSTAKA}

\section{Buku dan Jurnal}

Handayaningrat, Manajemen Konflik. PT. Gramedia Pustaka Utama. Jakarta. 1989.

Taliziduhu Ndraha, Kybernologi Ilmu Pemerintahan Baru. PT. Rineka Cipta, Jakarta, 2003.

Yaddy Supriadi, Keselamatan Penerbangan Teori \& Problematika, Telaga Ilmu Indonesia, Tangerang, 2012.

\section{Perundang-undangan}

Undang-undang Nomor 1 Tahun 2009 tentang Penerbangan.

Peraturan Menteri Perhubungan Nomor : PM. 41 Tahun 2011 tentang Organisasi dan Tata Kerja Kantor Otoritas Bandar Udara.

Peraturan Menteri Perhubungan Nomor : PM. 189 Tahun 2015 tentang Organisasi dan Tata Kerja Kementerian Perhubungan

Peraturan Menteri Perhubungan Nomor: PM. 80 Tahun 2017 tentang Program Keamanan Penerbangan Nasional.

Peraturan Menteri Perhubungan Nomor: PM. 59 Tahun 2015 tentang Kewenangan Inspektur Penerbangan

\section{Internet, Koran, dan Bahan Lain}

http://lontar.ui.ac.id., diakses pada tanggal 01 Februari 2018.

www.indonesiaairport.co.id, diakses pada tanggal 1 Februari 2018. 
Undang-undang Republik Indonesia Nomor 20 Tahun 2001 tentang Pemberantasan Tindak Pidana Korupsi.

Undang-undang Republik Indonesia Nomor 30 Tahun 2002 tentang Komisi Pemberantasan Tindak Pidana Korupsi.

Undang-undang Republik Indonesia Nomor 17 Tahun 2003 tentang Keuangan Negara.

Undang-undang Republik Indonesia Nomor 46 Tahun 2009 tentang Pengadilan Tindak Pidana Korupsi.

Peraturan Pemerintah Nomor 58 Tahun 2010 tentang Perubahan Atas Peraturan Pemerintah Nomor 27 Tahun 1983 tentang Pelaksanaan Kitab Undangundang Hukum Acara Pidana. 